сада Сибирского отделения Российской академии наук // Вестник Оренбургского государственного педагогического университета (Online). 2019. № 3 (31). C. 1-10. DOI: 10.32516/2303-9922.2019.31.1.

4. Бочанцева 3.П. Тюльпаны. Морфология, цитология и биология. Ташкент: Изд-во АН Узбекской CCP, 1962. $408 \mathrm{c}$.

5. Герасимович Л.В. Итоги первичной интродукции некоторых среднеазиатских тюльпанов в коллекции Центрального сибирского ботанического сада СО РАН // Успехи современной науки. 2017. Т. 1, № 8. C. 106-110.
6. Christenhusz M., Govaerts R., David J. etc. Tiptoe through the tulips - cultural history, molecular phylogenetics and classification of Tulipa (Liliaceae) // Botanical Journal of the Linnean Society. 2013. T. 172. P. 280-328.

7. Бейдеман И.Н. Методика изучения фенологии растений в растительных сообществах. Новосибирск: Наука, 1974. 256 с.

Исследования выполнены в рамках проекта VI.52.1.3 «Выявление путей адаптации растений к контрастным условиям обитания на популяционном и организменном уровнях", $A A A A-A 17-$ 117012610053-9 (номер госрегистрации).

\title{
TULIPA TSCHIMGANICA BOTSCHANTZ. IN THE COLLECTION OF THE CENTRAL SIBERIAN BOTANICAL GARDEN OF SIBERIAN BRANCH OF RUSSIAN ACADEMY OF SCIENCES
}

(C) 2019

\author{
Gerasimovich Lyudmila Vladimirovna, candidate of biological sciences, \\ junior researcher of Ornamental Plants Introduction Laboratory \\ Central Siberian Botanical Garden of Siberian Branch of Russian Academy of Sciences \\ (Novosibirsk, Russian Federation)
}

\begin{abstract}
The paper analyzes the features of seasonal development of Tulipa tschimganica Botschantz. in the conditions of the recipient region. Comparative morphometric characteristics of ex situ and in situ are given. Representatives of the species $T$. tschimganica growing in high mountains are successfully acclimatized in the Novosibirsk Region. Late flowering and resistance to viral disease variegation adds value to this species in floriculture and gardening in the spring. The temperature characteristics of the initial stages of phenophases are established. The beginning of flowering in six of ten years of observations occurred in the second decade of May. By duration, flowering can be characterized as short - 7-8 days, with an average duration of 10-12 days and a long one - 13-15 days, respectively. It was found that, despite the high rates of maximum and average daily temperatures, lower temperatures increase the flowering period of $T$. tschimganica. The flowering period in the recipient region, compared with the city of Tashkent, shifts by two months and starts from the second decade of May. The range of experimental plants morphometric parameters, such as plant height, leaf width, length and width of the ovary, and fruit width, increases. The rest of the studied parameters remained in situ. The study of the ontogeny of individuals grown from seeds collected from introduced plants is being carried out. To date, the plants are going through a long pregenerative period of ontogenesis. Successful completion of the full cycle of annual shoots development and the formation of highgrade mature seeds characterize this species as successful for introduction and use in gardening in Novosibirsk.

Keywords: Tulipa tschimganica Botschantz.; tulips; introduction; acclimatization of plants; adaptation; seasonal development; phenology; characteristics of initial stages of phenophases; morphometry of annual shoots; Novosibirsk.
\end{abstract}

$* * *$

УДК 58 (470.345) (045)

DOI $10.24411 / 2309-4370-2019-14108$

Статья поступила в редакцию 05.07.2019

\section{ЭКОЛОГО-БИОЛОГИЧЕСКИЕ ХАРАКТЕРИСТИКИ РОLYGONATUM MULTIFLORUM (L.) ALL. В УСЛОВИЯХ МОРДОВИИ}

(C) 2019

\author{
Лабутина Марина Викторовна, кандидат биологических наук, \\ доцент кафедры биологии, географии и методик обучения \\ Маскаева Татьяна Александровна, кандидат биологических наук, \\ доцент кафедры биологии, географии и методик обучения \\ Чегодаева Нина Дмитриевна, кандидат сельскохозяйственных наук, \\ доцент кафедры биологии, географии и методик обучения \\ Мордовский государственньй педагогический институт имени М.Е. Евсевьева \\ (2. Саранск, Российская Федераичия)
}

\footnotetext{
Аннотащия. В данной статье рассматриваются некоторые эколого-биологические особенности многолетнего травянистого растения - купены многоцветковой (Polygonatum multiflorum) cем. Liliaceae. Интерес к нему вызван тем, что численность этого вида лесостепной зоны сокращается вследствие возрастающей антропогенной нагрузки. Кроме того, купена является ценным лекарственным и декоративным растением. Исследования проводились в 2016-2017 гг. на территории Республики Мордовия, в условиях окрестностей крупного и провинциального городов. В ходе исследования были выявлены пространственная и возрастная структура четырех ценопопуляций купены. Определялись общие сроки вегетации купены и продолжитель-
} 
ность отдельных этапов развития растений. Установлен уровень потенциального и фактического плодообразования. Растения купены встречались разрозненно или группами, но чаще всего плотность составляла 3-4 особи/м². Исследованные ценопопуляции купены являются в основном нормальными, полночленными. Возобновление может осуществляться как за счет семян, так и вегетативно. Последнее наблюдается при благоприятных для купены условиях существования. Проведенные исследования подтвердили предположение, что купена является достаточно уязвимым лесным видом и существует реальная опасность утраты природного генофонда этого дикорастущего растения.

Ключевые слова: антропогенное воздействие; биоразнообразие; экология вида; ценопопуляция; место обитания; многолетнее травянистое растение; численность; плотность; морфологические признаки; возрастная структура; семенная продуктивность; фенологические фазы; смешанный лес; вегетационный период.

\section{Введение}

В настоящее время увеличение воздействия человека на окружающую природу приводит к тому, что все актуальнее становится проблема сохранения биоразнообразия. Особо важной задачей современной науки является выработка методов рационального использования растительных ресурсов, сохранение которых требует, прежде всего, изучения популяционной биологии видов $[1$, с. $191 ; 2$, с. 103]. Одной из проблем исследования ценопопуляций растений является определение лимитирующих факторов, популяционных приспособлений к существующим экологическим условиям, выявление демографических критериев (плотность, численность и др.). Необходимо и комплексное изучение репродуктивной биологии вида для разработки научных основ их сохранения.

Одним из таких видов, нуждающихся в охране, является купена многоцветковая (Polygonatum multiflorum), так как повсеместное уничтожение мест обитания этого вида привело к тому, что растение все реже встречается в естественных условиях [3, с. 4].

Polygonatum multiflorum (L.) All. - лесное многолетнее травянистое корневищное растение сем. лилейных (Liliaceae). Растение высотой 40-110 см. Корневище ползучее, мясистое, толстое, с резко выраженными междоузлиями, со следами отмерших стеблей. Стебель округлый, голый, дугообразно изогнутый. Листья очередные, продолговато-яйцевидные или эллиптические, до 11 см длиной, сверху зеленые, снизу серо-зеленые. Цветки правильные, белые, повислые, по 3-5 на цветоножках, выходящих из пазух листьев. Околоцветник трубчатый, шестизубчатый $[4$, с. 160]. Плод - шарообразная темносиняя сочная ягода с 1-2 семенами. Семена - крупные, округло-овальной формы, до 3,8 мм длиной.

Купена имеет ряд народных названий, отражающих особенности ее строения и оригинальных свойств. Во многих регионах России ее называют: соломонова печать, грыжник, золотник, кровавница, сердечник, пупник и др. [5, с. 15].

Купена используется в народной медицине и в ветеринарии. P. multiflorum, как и ландыш, является ядовитым растением с богатым содержанием гликозидов и алкалоидов, кроме этого, содержит крахмал, стерины и стероидные сапонины, флавоноиды, витамин С, каротиноиды [6, с. 46]. В медицине ее используют как кровоостанавливающее, жаропонижающее, обезболивающее, противовоспалительное и общеукрепляющее средство. В тибетской медицине корневища купены используют как общеукрепляющее и адаптогенное средство, а также для приготовления лекарств против старения организма [7, с. 159].

P. multiflorum имеет определенное декоративное значение. Используется в ландшафтном озеленении и озеленении приусадебных участков [8, с. 179]. В связи с этим интерес к этому дикорастущему виду постоянно растет.
На территории Мордовии известно 2 вида: купена душистая или лекарственная (Polygonatum odoratum (Will.) Druce) [9, с. 108], многоцветковая (Polygonatum myltiflorum (L.) All.) и их гибрид [10, с. 90].

Купена многоцветковая является одним из наиболее уязвимых компонентов естественных лесных фитоценозов, тем не менее она не включена (подобно ландышу) в дополнительный список редких и уязвимых сосудистых растений Республики Мордовия, нуждающихся в постоянном контроле и наблюдении [11]. В других регионах этот вид давно занесен в региональные Красные книги $[12$, с. $5 ; 13 ; 14$, c. 248], поэтому изучение распространения, экологии популяции P. multiflorum имеет важное значение для исследования растительного мира и сохранения биоразнообразия на территории Мордовии.

Целью нашего исследования явилось изучение некоторых эколого-биологических аспектов купены многоцветковой в условиях Мордовии.

В задачи исследования входило:

- изучение численной и пространственной характеристики купены многоцветковой;

- определение количественных показателей морфологических признаков вегетативных органов купены многоцветковой;

- выявление возрастной структуры популяции купены многоцветковой;

- установление уровня семенной продуктивности купены на исследуемых площадках.

\section{Место и методы исследования}

Исследование проводилось в 2016-2017 гг. в лесных фитоценозах:

- вблизи р.п. Николаевка г.о. Саранск (ценопопуляция 1). Рабочий поселок Николаевка образован в 1969 г., расположен на берегу р. Инсар, в 7 км от районного центра и в 2 км от железнодорожной станции Ялга с населением 6,2 тыс. чел. [15, с. 286]. Николаевский лес является местом сбора грибов, ягод, а также отдыха жителей поселка;

- юго-западной (ценопопуляция 2) и северо-западной (ценопопуляция 3) части окрестностей г. Саранска. Город Саранск - столица Республики Мордовия, промышленный и культурный центр республики с населением 302285 чел. С экологических позиций лесопарк, расположенный в юго-западной части города, считается наиболее чистым, за ним на втором месте - северо-западный лесной массив. Обе территории активно используются жителями города для отдыха [16, с. 152];

- вблизи г. Краснослободска (ценопопуляция 4) Республики Мордовия. Краснослободск - административный центр Краснослободского района Республики Мордовия, с населением 9713 чел., характеризуется относительно слабым уровнем загрязнения. Лесной массив расположен вблизи города, выбранные площадки располагались в глубине леса, на удалении не менее 5 км [17, с. 123]. 
Лабутина М.В., Маскаева Т.А., Чегодаева Н.Д.

Изучение купены проводилось методом площадок. В каждом из районов обследовалось по пять площадок размером $10 \times 10 \mathrm{M}^{2}$, на каждой подсчитывалось общее количество растений купены, их фазы развития. Фенологические наблюдения проводились по методике И.Н. Бейдемана [18]. На модельных площадках проводилось биометрическое изучение всех растений. По методике И.В. Вайнагий [19, с. 826] определялось: потенциальное и реальное плодообразование, статистическая обработка материала по методике Б.А. Доспехова [20].

\section{Результаты исследования и их обсуждение}

Геоботаническое изучение условий обитания купены характеризовалось сходным видовым составом лесной растительности исследуемых территорий. Так, первый ярус смешанного леса образован березой бородавчатой (Betula pendula Roth), дубом черешчатым (Quercus robur L.), кленом платановидный (Acer platanoides L.), осиной обыкновенной (Populus tremula), липой сердцелистной (Tilia cordata); 2 ярус представлен лещиной обыкновенной (Corylus avellana), черемухой обыкновенной (Prunus padus L.), рябиной обыкновенной (Sórbus aucupária). Единично встречались бересклет бородавчатый (Euonymus verrucosus), ежевика (Rubus caesius), шиповник майский (Rosa majalis).

Травянистый ярус чаще всего был представлен следующими видами растений: лапчатка серебристая (Potentilla argentea L.), щитовник мужской (Dryopteris filix-mas (L.) Schott.), копытень европейский (Asarum europaeum L.), сныть обыкновенная (Aegopodium podagraria L.), ландыш майский (Convallaria majalis L.), ветрица лютиковая (Anemone ranunculoides L.), осока волосистая (Carex pilosa Scop.), вероника длиннолистая (Veronica longifolia L.), гравилат городской (Geum urbanum L.), чистотел большой (Chelidonium majus L.), сочевичник весенний (Lathyrus vernus (L.) Bernh.), будра плющевидная (Glechoma hederacea L.), звезчатка ланцетовидная (Stellaria holostea L.) и др.

Весной почки возобновления у купены выходят на поверхность почвы и дают начало надземным побегам. В 2016 г. начало вегетации у купены приходилось на конец апреля и первую декаду мая (таблица 1). Период бутонизации наступил в середине мая и составил около 7-9 дней. Цветение купены начиналось с 18-21 мая. Цветение непродолжительное, длилось в течение 10-16 дней и происходило в соцветии в восходящем порядке. Период созревания плодов охватывал весь июль-август. Завершение плодоношения отмечалось в первой декаде сентября. С 8-11 сентября наблюдалось пожелтение листьев и постепенное отмирание надземных побегов. К концу вегетационного периода на корневище купены уже сформированы почки побегов будущего года, В целом период вегетации годичных побегов у купены многоцветковой составил 156-159 дней, и только в Краснослободском лесу у побегов купены период вегетации составил 165 дней, вследствие затянувшегося периода плодоношения.

Всего в исследуемых ценопопуляциях было изучено 1234 вегетирующих побега купены: в 2016 г. их насчитывалось 449, в 2017 г. - 785. Вегетирующие побеги купены на изученных площадках встречались в основном рассеянно. Плотность (из расчета особь $\left./ \mathrm{M}^{2}\right)$ и численность в 2016 г. была невысока на большинстве участков 2,6-4,7 особь/м² (таблица 2). Исключение в оба года исследования составляла ценопопуляция 4 (Краснослободский лес), в ней купена встречалась довольно часто - 33,6-37,4 особь/ $\mathrm{M}^{2}$. Следует отметить, что в 2017 г. численность купены на площадках выросла в 3,2-5,5 раза, в условиях пригородного Николаевского леса всего в 1,4 раза.

Таблица 1 - Фенологическое развитие Polygonatum multiflorum (2016 г.)

\begin{tabular}{|c|c|c|c|c|c|c|}
\hline \multirow{2}{*}{$\begin{array}{c}\text { Место } \\
\text { исследования }\end{array}$} & \multicolumn{7}{|c|}{$\begin{array}{c}\text { Сроки } \\
\text { Начало } \\
\text { вегетации }\end{array}$} & Бутонизация & Цветение & Плодоношение & $\begin{array}{c}\text { Отмирание } \\
\text { побегов }\end{array}$ & $\begin{array}{c}\text { Вегетации } \\
\text { (день) }\end{array}$ \\
\hline ценопопуляция 1 & $\frac{28.04-12.05}{15}$ & $\frac{13.05-20.05}{8}$ & $\frac{21.05-01.06}{12}$ & $\frac{02.06-07.09}{98}$ & $\frac{08.09-30.09}{23}$ & 156 \\
\hline ценопопуляция 2 & $\frac{26.04-12.05}{17}$ & $\frac{13.05-19.05}{7}$ & $\frac{20.05-01.06}{13}$ & $\frac{02.06-08.09}{99}$ & $\frac{09.09-30.09}{22}$ & 158 \\
\hline ценопопуляция 3 & $\frac{26.04-10.05}{15}$ & $\frac{11.05-18.05}{8}$ & $\frac{18.05-02.06}{16}$ & $\frac{03.06-08.09}{98}$ & $\frac{09.09-30.09}{22}$ & 159 \\
\hline ценопопуляция 4 & $\frac{23.04-10.05}{18}$ & $\frac{11.05-19.05}{9}$ & $\frac{20.05-29.05}{10}$ & $\frac{30.05-10.09}{104}$ & $\frac{11.09-04.10}{24}$ & 165 \\
\hline
\end{tabular}

Таблица 2 - Некоторые эколого-биологические характеристики Polygonatum multiflorum

\begin{tabular}{|c|c|c|c|c|}
\hline \multirow{2}{*}{$\begin{array}{c}\text { Место } \\
\text { исследования }\end{array}$} & \multirow{2}{*}{$\begin{array}{c}\text { Плотность } \\
\text { растений, } \\
\text { особь/м² }\end{array}$} & \multirow{2}{*}{$\begin{array}{c}\text { Число } \\
\text { репродуктивных } \\
\text { побегов, \% }\end{array}$} & \multicolumn{2}{|c|}{$\begin{array}{c}\text { Морфометрическая характеристика } \\
\text { репродуктивных побегов }\end{array}$} \\
\hline & & & высота побега, см & число листьев, шт. \\
\hline \multicolumn{5}{|c|}{2016 г. } \\
\hline ценопопуляция 1 & $2,6 \pm 0,83$ & $68,3 \pm 5,07$ & $74,9 \pm 7,00$ & $18,2 \pm 0,96$ \\
\hline ценопопуляция 2 & $4,7 \pm 0,88$ & $26,6 \pm 1,67$ & $58,5 \pm 7,75$ & $15,0 \pm 2,52$ \\
\hline ценопопуляция 3 & $4,0 \pm 0,34$ & $22,5 \pm 1,21$ & $61,5 \pm 3,78$ & $18,8 \pm 2,21$ \\
\hline ценопопуляция 4 & $33,6 \pm 6,01$ & $39,7 \pm 9,41$ & $72,4 \pm 2,56$ & $17,9 \pm 1,52$ \\
\hline \multicolumn{5}{|c|}{2017 г. } \\
\hline ценопопуляция 1 & $3,7 \pm 0,64$ & $74,0 \pm 5,08$ & $67,5 \pm 4,48$ & $16,1 \pm 0,76$ \\
\hline ценопопуляция 2 & $15,6 \pm 0,49$ & $63,5 \pm 1,42$ & $71,1 \pm 1,06$ & $19,3 \pm 0,54$ \\
\hline ценопопуляция 3 & $21,8 \pm 0,34$ & $79,2 \pm 1,07$ & $76,8 \pm 0,95$ & $20,1 \pm 0,39$ \\
\hline ценопопуляция 4 & $37,4 \pm 0,25$ & $39,2 \pm 8,62$ & $74,7 \pm 2,12$ & $18,3 \pm 0,47$ \\
\hline
\end{tabular}


В составе ценопопуляций купены присутствовали особи разного возраста: ювенильные, имматурные, вергинильные, генеративные и сенильные, что в целом характеризует ценопопуляции купен как нормальные, полночленные. Однако в ценопопуляции 2 и ценопопуляции 3 в возрастном спектре достаточно большую долю занимали сенильные и субсенильные растения, в ценопопуляции 4 в возрастном спектре преобладали молодые, вегетирующие растения. Количество цветущих и плодоносящих побегов составило по исследуемым площадкам от $22,5 \%$ до $79 \%$ (таблица 2). В Краснослободском лесу процент репродуктивных побегов в годы исследования был относительно стабилен 39,2-39,7\%. Достаточно высок процент репродуктивных побегов купены был и в ценопопуляции 1 - 68-74\%. В условиях пригородных лесов г. Саранска этот показатель колебался от 22-26\% в 2016 г. до 63-79\% в 2017 г.

Высота репродуктивных побегов составила от 58,5 см до 115 см, нецветущие побеги купены в высоту достигали только 31-40 см. Неодинаковым было у них количество листьев: на вегетативных побегах насчитывалось от 8 до 12 листьев, на репродуктивных побегах - от 15 до 20 листьев. Очевидно, что взрослые репродуктивные побеги купены существенно отличаются по морфометрическим параметрам от вегетативных побегов.

Одним из критериев репродуктивных возможностей вида является его семенное воспроизведение. По предложенной методике [19, с. 826] определялось среднее по площадке число цветков (потенциальное плодообразование) на побеге купены. Производным от потенциального плодообразования является реальное плодообразование, характеризующиеся числом завязавшихся плодов.

На исследуемых площадках на репродуктивных побегах купены в среднем закладывалось в 2016 г. от 10 (ценопопуляция 3) до 23 цветков (ценопопуляция 1), в 2017 г. - 20-26 цветков (рис. 1). После цветения на побегах купены оставалось не более 3-8 плодов в 2016 г. и 5-15 плодов в 2017 г. (рис. 2). Таким образом, в 2016 г. плодообразование составило минимально - $21 \%$ (ценопопуляция 4), максимальное $48 \%$ в ценопопуляции 2 (рис. 3). В 2017 г. минимальное плодообразование наблюдалось в ценопопуляции $1-23,8 \%$, максимальное - 58,5\% в ценопопуляции 2 и $65,7 \%$ в ценопопуляции 3 . Замечено, что чаще всего сохранялись плоды, образовавшиеся из цветков средних узлов побега.

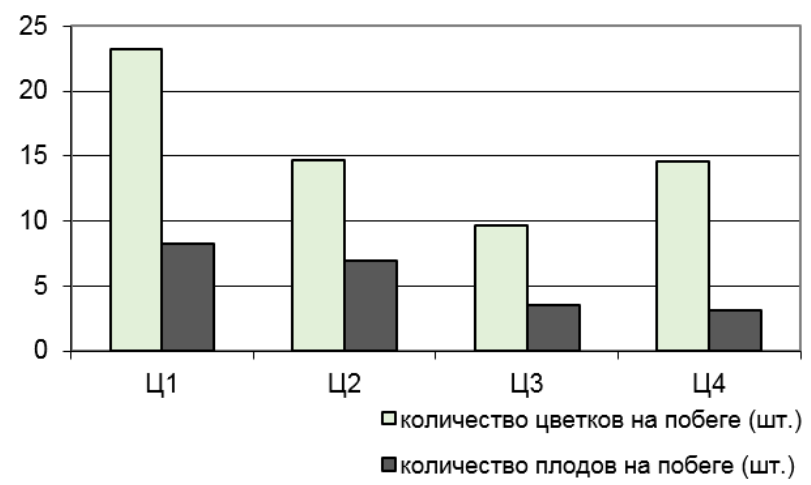

Рисунок 1 - Цветение и плодоношение купены многоцветковой в условиях Мордовии в 2016 г.

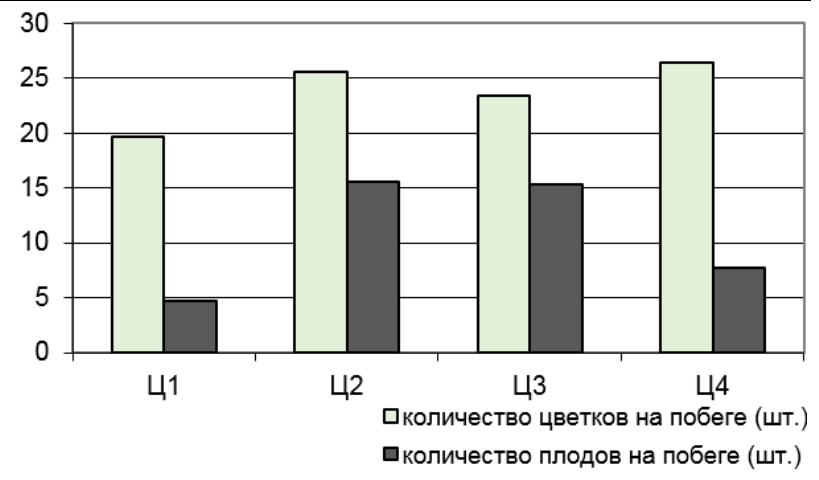

Рисунок 2 - Цветение и плодоношение купены многоцветковой в условиях Мордовии в 2017 г.

В результате исследования было выявлено, что часто плоды купены многоцветковой повреждаются насекомыми и их личинками, что ведет к их преждевременному опадению. Так, на участках ценопопуляции 1 при вскрытии сохнущих ягод купены внутри были найдены многочисленные ходы, что приводит к высыханию плодов и повреждению семян.

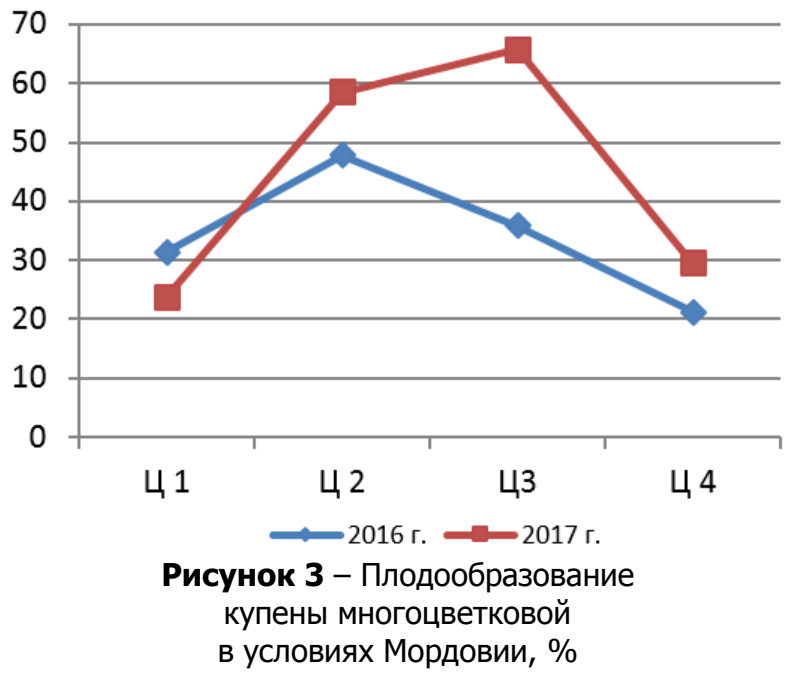

Но, несмотря на достаточно высокий процент плодообразования, воспроизведение купены многоцветковой при помощи семенного размножения происходит плохо и достаточно медленно. Это связано с тем, что семена имеют продолжительный период покоя вследствие физиологической незрелости зародыша семени. Кроме того, они очень быстро теряют всхожесть, и нуждаются в стратификации. Прорастание семян подземное. Сеянцы не капризны, но развиваются медленно [4, с. 162]. Зацветает и плодоносит купена только на 10-15-й год жизни, что подтверждает мнение о медленном воспроизведении купены.

Таким образом, распространение купены на территории исследуемых ценопопуляций неравномерное, на одних территориях побеги купены встречаются единично и рассеянно, на других - достаточно обильно. Такое распространение предполагает, что купена способна воспроизводиться как семенами (единично), так и вегетативно, образуя клоны. Вегетативное размножение в большей степени наблюдается в ценопопуляции 4, где антропогенное воздействие, на наш взгляд, минимальное. Известно, что при выращивании купены в культуре применяется только вегетативное размножение [21, с. 30]. 
Лабутина М.В., Маскаева Т.А., Чегодаева Н.Д.

Выводы

Проведенные исследования подтвердили предположение о том, что купена является уязвимым лесным видом. Плотность и численность ценопопуляций 1, 2 и 3 минимальны или непостоянны при активном присутствии человека на данных территориях. Растения, обладая коротким хрупким корневищем, крайне чувствительны к вытаптыванию, не образуют в лесном фитоценозе сплошного покрова. В пригородных лесах г. Саранска ценопопуляции купены регрессивного типа. Растения купены встречаются единично или небольшими группами, чаще всего плотность растений составляет 3-4 особ./ ${ }^{2}$. Ocoбенности произрастания свидетельствуют, что возобновление может осуществляться как за счет семян, так и вегетативно. Последнее наблюдается при благоприятных для купены условиях существования, семенное же крайне затруднено. Хотя купена считается нетребовательным к условиям обитания растением, она, как типично лесной вид, является тенелюбивой, предпочитает нейтральные плодородные почвы со средним уровнем залегания грунтовых вод [10, с. 90].

P. multiflorum требуется внести в список уязвимых видов, в категорию находящихся под угрозой, так как существует реальная опасность утраты природного генофонда декоративного дикорастущего растения.

\section{Список литературы:}

1. Гиляров А.М. Популяционная экология. М.: Изд-во МГУ, 1990. 191 с.

2. Куликова Г.Г. Охрана растительного покрова. М.: Изд-во МГУ, 1992. 103 с.

3. Боронникова С.В. Репродуктивная биология некоторых декоративных цветущих видов растений Предуралья: автореф. дис. ... канд. биол. наук. Пермь, $1995.19 \mathrm{c}$.

4. Ивашина Л.И. Семейство спаржевых // Жизнь растений / под ред. А.Л. Тахтаджяна. 1982. Т. 6. C. $160-162$.

5. Турова А.Д. Лекарственные растения СССР и их применение. М.: Изд-во «Медицина», 1974. 426 с.

6. Голышенков П.П. Лекарственные растения и их использование. Саранск: Мордов. кн. изд-во, 1990. $302 \mathrm{c}$.

7. Баторова С.М., Яковлев Г.П., Николаев С.М., Самбуева 3.Г. Растения тибетской медицины: Опыт фармакогностического исследования. Новосибирск: Изд-во «Наука», Сиб. отд-ние, 1989. 159 с.

8. Тавлинова Г.К. Приусадебное цветоводство. Л.: Изд-во «Агропромиздат», 1989. 179 с.
9. Баландин С.А., Баландина Т.П. Купена лекарственная // Биологическая флора Московской области. № 1. М.: Изд-во МГУ, «Аргус»,1995. С. 108-116.

10. Силаева Т.Б., Кирюхин И.В., Чугунов Г.Г. Сосудистые растения Республики Мордовия (конспект флоры): монография / под ред. Т.Б. Силаевой. Саранск: Изд-во Мордов. ун-та, 2010. 352 с.

11. Красная книга Республики Мордовия. в 2 т. T. 1: Редкие виды растений и грибов. Изд. 2-е, перераб. / сост. Т.Б. Силаева. Саранск: Изд-во Мордов. ун-та, 2017. 409 с.

12. Балахонова Н.С. Состояние ценопопуляций редких и охраняемых видов растений на юго-западе города Москвы: автореф. дис. ... канд. биол. наук. M., 2006. 26 c.

13. Красная книга Вологодской области. Т. 2. Растения и грибы / отв. ред. Г.Ю. Конечная, Т.А. Суслова. Вологда: ВГПУ, Изд-во «Русь», 2004. 360 с.

14. Красная книга Смоленской области. Книга редких и находящихся под угрозой исчезновения видов животных и растений / отв. ред. Н.Д. Круглов. Смоленск: Смоленский государственный педагогический институт, 1997. 294 с.

15. Мордовия: энциклопедия в 2-х т. Т. 2. Саранск: Мордовское кн. издательство, 2004. 699 с.

16. Все о Мордовии: энциклопедический справочник / сост. Е.М. Голубчик [и др.]. Саранск: Изд-во Мордов. ун-та, 1997. 713 с.

17. Поршаков А.Н. Города и села Мордовии. Саранск: Мордов. кн. изд., 1977. 373 с.

18. Бейдеман И.Н. Методика изучения фенологии растений и растительных сообществ. Новосибирск: Изд-во «Наука», 1979. 102 с.

19. Вайнагий И.В. О методике изучения семенных растений // Ботанический журнал. 1974. Т. 59, вып. 6. С. 826-832.

20. Доспехов Б.А. Методика полевого опыта (с основами статистической обработки результатов исследований). М.: Агропромиздат, 1985. 351 с.

21. Головкин Б.Н., К Китаева Л.А., Немченко Э.П. Декоративные растения СССР. М.: Изд-во «Мысль», 1986. $320 \mathrm{c}$.

Исследование выполнено в рамках внутривузовского гранта Мордовского государственного педагогического института им. М.Е. Евсевьева по теме: «Разработка научно- и учебно-методического обеспечения дисциплины "Теория эволюции» для студентов бакалавров 4-5 курсов очной формы обучения по направлению подготовки 44.03.05 Педагогическое образование, профиль Биология. Химия, Биология. География».

\section{ECOLOGICAL AND BIOLOGICAL CHARACTERISTICS OF POLYGONATUM MULTIFLORUM (L.) ALL. IN MORDOVIA}

(C) 2019

Labutina Marina Viktorovna, candidate of biological sciences, associate professor of Biology, Geography and Methods of Teaching Department

Maskaeva Tatiana Aleksandrovna, candidate of biological sciences, associate professor of Biology, Geography and Methods of Teaching Department

Chegodaeva Nina Dmitrievna, candidate of agricultural sciences, associate professor of Biology, Geography and Methods of Teaching Department Mordovian State Pedagogical Institute named after M.E. Evseviev (Saransk, Russian Federation)

Abstract. The paper discusses some of the ecological and biological characteristics of a perennial herbaceous plant - Polygonatum multiflorum seeds. Liliaceae. It is of interest due to the fact that the number of this species of 
the forest-steppe zone is reduced due to the increasing anthropogenic load. In addition, $P$. multiflorum is a valuable medicinal and ornamental plant. The studies were conducted in 2016-2017 on the territory of the Republic of Mordovia, in the surroundings of large and provincial cities. The study revealed the spatial and age structure of the four coenopopulations plants. The general terms of the vegetation $P$. multiflorum and the duration of the individual stages of plant development were determined. The level of potential and actual fruit formation is established. P. multiflorum plants were found scattered or in groups, but most often, the density was 3-4 individuals $/ \mathrm{m}^{2}$. The studied coenopopulations P. multiflorum are mostly normal, full-term. Renewal can be carried out both due to seeds and vegetatively. The latter is observed under favorable conditions for the $P$. multiflorum of existence. The studies have confirmed the view that the $P$. multiflorum is a fairly vulnerable forest species and there is a real risk of loss of the natural gene pool of this wild plant.

Keywords: anthropogenic impact; biodiversity; species ecology; coenopopulation; habitat; perennial herb; abundance; density; morphological characteristics; age structure; seed productivity; phenological phases; mixed forest; growing season.

\title{
СРАВНИТЕЛЬНЫЙ АНАЛИЗ ПРОСТРАНСТВЕННОГО РАСПРЕДЕЛЕНИЯ СОЛЁНОСТИ И БИОМАССЫ НЕКТОНА И НЕКТОБЕНТОСА В ЭСТУАРИЯХ КРУПНОЙ РАВНИННОЙ РЕКИ РАЗДОЛЬНАЯ И ГОРНОЙ РЕКИ СУХОДОЛ (ЯПОНСКОЕ МОРЕ)
}

\author{
Милованкин Павел Геннадьевич, научный сотрудник лаборатории прикладной биоценологии \\ Катайкина Ольга Игоревна, инженер лаборатории промысловой океанографии \\ Тихоокеанский филиал Всероссийского научно-исследовательского института \\ рыбного хозяйства и океанографии (г. Владивосток, Российская Федерация)
}

\begin{abstract}
Аннотация. В данной статье рассматриваются два эстуария - крупной равнинной реки Раздольная и горной реки Суходол (Японское море). Приводятся данные гидрологических съёмок на этих эстуариях и показаны зоны распространения вод различной солёности. Приведены графики изменения биомасс некоторых гидробионтов вдоль русла реки. Проведённые исследования показали, что в реку Раздольная воды с солёностью $>5 \%$ проникают вверх по главному руслу на 15 км. В реке Суходол бывает, что практически весь эстуарий занят солёной водой, а пресная вода прослеживается в слое воды толщиной не более 0,5 м не ближе 500 м до устья реки. В р. Раздольной имеется тенденция к росту уловов гидробионтов от внешнего эстуария к внутреннему (из моря в реку) до максимальных значений на расстоянии 5 км от устья с последующим плавным понижением вверх по течению реки. В р. Суходол удельная биомасса плавно понижается от верха реки до минимума на отметке в 0,4 км от устья с резким ростом в районе самого устья (приустьевая лагуна и морское побережье) и последующим плавным понижением. Удельная биомасса гидробионтов во внутренних эстуариях рек Раздольная и Суходол составила 6,7 и 4,0 г/м² соответственно.

Ключевые слова: эстуарий; внутренний эстуарий; внешний эстуарий; Японское море; залив Петра Великого; Амурский залив; река Раздольная; река Суходол; градиент солёности; биомасса; солёность; зоны барьерных солёностей; нектон; нектобентос; индекс Симпсона; выравненность видов; индекс разности выравненностей; Planiliza haematocheila; Tribolodon spp.; Eriocheir japonica; закидной невод; донный трал.
\end{abstract}

\section{Введение}

Эстуарий - это полузакрытый прибрежный водоём, который связан с морем постоянно или периодически, имеет солёность, отличную от солёности прилегающего открытого океана из-за пресноводного стока, и включает своеобразную биоту [1]. По структуре вод эстуарии разделяются на внутреннюю и внешнюю части. Поверхностный слой во внутреннем эстуарии занят пресной или почти пресной речной водой, а у дна (если глубина достаточно большая) находится клин солоноватых вод. Во внешнем эстуарии поверхностный слой занят шлейфом солоноватых вод, а придонный слой занимают солёные морские воды [2, рис. 1.43-1.45].

Наиболее изученные эстуарии Приморского края - p. Раздольной и р. Суходол - относятся, по классификации Е.И. Барабанщикова, к разным типам. Эта классификация разработана как по морфологическим характеристикам, так и по качественному и количественному составу зоопланктона. Река Раздольная относится к равнинным рекам с протяжённой эстуарной зоной, река Суходол относится к горным рекам с короткой эстуарной зоной [3]. Речной сток р. Раздольной оценён в 2,46 км ${ }^{3}$ с пиком 19.05.2011 г. в $730 \mathrm{~m}^{3} / \mathrm{c}$ [4], многолетний среднегодовой расход составляет $76 \mathrm{~m}^{3} / \mathrm{c}$ [5], расход р. Суходол оценён в 2,0 м³/с [6].

На эстуариях этих рек исследовано поведение главных биогенных элементов в период малой и большой воды [5], исследована карбонатная система эстуария р. Раздольной [7], кратко описаны и проиллюстрированы расположение речных вод, областей внутреннего и внешнего эстуария по нескольким съёмкам [8], выполнена оценка первичной продукции [9], проведено изучение факторов формирования первичной продукции в период ледостава [10], показано распределение рыб и беспозвоночных [11-19] и изучены закономерности формирования и разрушения гипоксии в эстуариях залива Петра Великого [4].

Но не показана обобщённая схема распространения вод различной солёности в эстуариях рек Раз- 